\title{
ENCOURAGING CONSUMER ETHNOCENTRISM IN THE FUNCTION OF DOMESTIC FOODSTUFFS CONSUMPTION
}

\author{
Mira Rakic ${ }^{1}$, Beba Rakic ${ }^{2}$, Ljiljana Stanojevic ${ }^{3}$ \\ *Corresponding author E-mail: rakic.mira@gmail.com
}

\begin{abstract}
A R T I C L E I N F O
A B S T R A C T

Original Article

Received: 10 July 2018

Accepted: 27 November 2018

doi:10.5937/ekoPolj1902341R

UDC 338.439.63:659.117.3

Keywords:

consumer ethnocentrism, consumers, foodstuffs, Serbia

The objective of this study was to examine the actors and the activities of the actors influencing consumer ethnocentrism in the consumption of domestic foodstuffs in Serbia. To do this, the items of the modified Consumer Ethnocentric Tendencies Scale were used as the framework for the focus-group interview. The two basic questions were 1) who (which actors) and 2) what (which activities) should actors take in order to encourage consumer ethnocentrism. The findings have interesting implications for actors with respect to marketing activities. The results show that governments, schools, producers, retailers, the media and JEL: Q13, M31 consumers need to promote ethnocentrism in Serbia. There are two basic conclusions with the recommendations for actors' activities in order to encourage ethnocentrism: first, consumer behavior influencing the profit of companies and the gross domestic product of Serbia and second, all other actors can influence the consumer awareness of the importance of ethnocentric behavior in consumption.
\end{abstract}

(C) 2019 EA. All rights reserved.

\section{Introduction}

Agricultural and food sector has a very important role in the economic development of Republic of Serbia (Đurić et al., 2017). Serbia has the potential for production and processing of high quality and healthy products and development of conventional, integral and organic agricultural production for the needs of the domestic market and export (Cvijanović et al., 2016). Households buy food products that vary from cheap to expensive, from healthy to unhealthy, from basic to value-added. Beside the nutritional,

1 Mira Rakic, Ph.D., Full Professor, Faculty of Business Studies, Bulevar marsala Tolbuhina 8, Belgrade, Serbia, Phone: +381 11 2203011, E-mail: rakic.mira@gmail.com, ORCID ID (http://orcid.org/0000-0003-4937-7645)

2 Beba Rakic, Ph.D., Full Professor, Faculty of Business Studies, Bulevar marsala Tolbuhina 8, Belgrade, Serbia, Phone: +381 11 2203011, E-mail: brakic@gmail.com, ORCID ID (http://orcid.org/0000-0001-7779-4548)

3 Ljiljana Stanojević, Ph.D., Associate Professor, MEF, Jevrejska 24, Belgrade, Serbia, Phone: +381 11264 3390, E-mail: ljstanojevic@gmail.com ORCID ID (https://orcid. org/0000-0002-4157-4989)

http://ea.bg.ac.rs 
economic factors have a major and often decisive significance on a households' ability to afford certain food products. Income, price and housing costs have a significant influence on the purchase of food products (Kovljenić, Savić, 2017). The importance of the agro-food sector for the development of Serbia and the interdependence between $\mathrm{CE}$ and the consumption of domestic foodstuffs influenced the subject matter of this paper. In the introductory part, the related literature is reviewed. Ethnocentrism and CE (the factors influencing CE, the types of ethnocentric consumers) are first presented. In addition, in the introductory part, the concepts of local, regional and traditional foods are presented. In this paper, the term "domestic food product" is used for local, regional and traditional food products. After presenting the literature in the field of consumer ethnocentrism (CE) and domestic food products, the focus-group method applied in the research studies described. Then, the results of the research are described and the discussion is presented. At the end of the paper, the conclusions and recommendations for the actors and their activities are given.

\section{Literature review}

The term "ethnocentrism" is introduced by Sumner(1906). Sumner defines ethnocentrism as: "... the view of things in which one's own group is the center of everything, and all others are scaled and rated with reference to it... Each group nourishes its own pride and vanity, boasts itself superior, exalts its own divinities and looks with contempt on outsiders" (Sumner, 1906, p. 13). The concept of ethnocentrism implies the people who view their own group as the center of the universe, interpret other social units from the perspective of their own group, and reject the persons who are culturally dissimilar, while blindly accepting those who are culturally like themselves (Booth, 1979; Shimp, Sharma, 1987).

The concept of consumer ethnocentrism is introduced by Shimp and Sharma (1987). "From the perspective of ethnocentric consumers, purchasing imported products is wrong because, in their minds, it hurts the domestic economy, causes loss of jobs, and is plainly unpatriotic; products from other countries (i.e., out groups) are objects of contempt to highly ethnocentric consumers" (Shimp, Sharma, 1987, p. 280). Consumer ethnocentrism remains fervent despite globalization and represents one of the strongest import blockades of our time (Shankarmahesh, 2006). CE is also called "patriotic consumption behavior" (Schnettler et al, 2011).

Research on CE has largely focused on consumer choices between domestic and imported products. There are a small, but growing, number of the studies of regional ethnocentrism, or CE at a subnational level, or in an inter-regional context (FernándezFerrín, Bande-Vil, 2013; Fernández-Ferrín, Bande, Galán-Ladero, 2017; Ouellet, 2007; Poon, Evangelista, Albaum, 2010).

Shimp and Sharma (1987) formulated and validated an instrument called Consumer Ethnocentric Tendencies Scale (CETSCALE) so as to measure consumers' ethnocentric tendencies related to purchasing foreign- versus American-made products. CETSCALE 
is translated into other languages and tested in different countries and different product categories (Bianchi and Mortimer, 2015; Orth, Firbasová, 2003; Schnettler et al, 2011; Šmaižien, Vaitkien, 2014). Modificated CETSCALE is tested in Serbia (Gašević, Tomašević, Vranješ, 2017; Kragulj, Parežanin, Miladinović, 2017; Marinković, Stanišić, Kostić, 2011).

The majority of prior studies consider the factors influencing $\mathrm{CE}$ and the types of consumers with the degrees of ethnocentrism (based on CETSCALE). In the literature, the following factors that have an influence on ethnocentric consumer behavior were investigated most in relation to the consumption of local foodstuffs: the health issues (Schnettler et al, 2011), the country-of-origin (COO) (Chung, Boyer, Han, 2009; Schnettler et al, 2011; Verlegh, Steenkamp, Meulenberg, 2005), the demographic factors like age, etc. (Alfnes, 2004; Balabanis et al., 2002; Huddleston, Good, Stoel, 2001; Javalgi et al., 2005; Shimp, Sharma, 1987; Verbeke, Ward, 2006), gender (Alfnes, 2004; Balabanis et al., 2002; Chung et al., 2009; Javalgi et al., 2005; Schnettler et al, 2011; Shimp and Sharma, 1987), income (Balabanis et al., 2002; Javalgi et al., 2005; Schnettler et al, 2011; Verbeke, Ward, 2006), education (Balabanis et al., 2002; Javalgi et al., 2005; Schnettler et al, 2011; Verbeke, Ward, 2006) etc. COO implies that consumers use the product origin as an attribute related to its quality, either alone or in combination with other attributes (Schnettler et al, 2011). Elderly people show stronger ethnocentric tendencies than the younger (Alfnes, 2004; Balabanis et al., 2002; Huddleston, Good, \& Stoel, 2001; Javalgi et al., 2005; Shimp, Sharma, 1987; Verbeke, Ward, 2006). Various studies have determined stronger ethnocentric tendencies in women (Alfnes, 2004; Balabanis et al., 2002; Chung et al., 2009; Javalgi et al., 2005; Schnettler et al, 2011; Shimp and Sharma, 1987). Education and income tend to present a negative relation to ethnocentrism (Balabanis et al., 2002; Javalgi et al., 2005; Schnettler et al, 2011; Verbeke, Ward, 2006). Consumers residing in rural zones have been found to demonstrate a stronger rejection of imported products (Alfnes, 2004; Schnettler et al, 2011).

The previous studies have indicated consumers (Autio et al., 2013; Arsil et al., 2013; Bianchi, Mortimer, 2015; Schnettler et al, 2011), governments (Bianchi, Mortimer, 2015; Coderre et al., 2010; Ilbery et al., 2006), producers (Bianchi, Mortimer, 2015; Paustian, Reinecke, Theuvsen, 2016), retailers (Bianchi, Mortimer, 2015; Carpio, Isengildina-Massa, 2009; Darby et al., 2008), schools (Bianchi, Mortimer, 2015; Nabham, 2002) and media (Bianchi, Mortimer, 2015; Nabham, 2002) as the actors responsible for $\mathrm{CE}$ fostering.

The growing awareness of environmental and health-related issues, the healthy lifestyle led by consumers influence consumer interest in the origins of the food they purchase and the transparency of the food chain (Autio et al., 2013; Arsil et al., 2013; Bianchi and Mortimer, 2015; Costanigro et al., 2014; Rakic, Rakic, 2015a, Rakic, Rakic, 2015b). Consumers are willing to pay a premium for unconventional products (Costanigro et al., 2014). 
Governments are also showing an increasing interest in supporting and promoting local foods (Bianchi, Mortimer, 2015; Coderre et al., 2010; Ilbery et al., 2006). Sustainabilityoriented actors in the macro-environment (regulators and governments, the general public, environmental and social pressure groups, NGOs, neighbourhood communities, the media and schools) have the roles of setting "the patterns of sustainable behavior", promotions, pressures and controls of actors' sustainable behaviour (Rakic, Rakic, 2018).

Producers and retailers need to develop campaigns explaining how consuming local food supports local businesses and farmers (Bianchi, Mortimer, 2015). Some retailers and culinary experts have better understood this opportunity and have invested heavily into the production, distribution and serving of domestic food as a way to connect with consumers and increase profits (Bianchi, Mortimer, 2015; Carpio, Isengildina-Massa, 2009; Darby et al., 2008). Farmers, processors and retailers can differentiate their products by using labels and by providing information about the origin or the geographical indications (GI) of their local, regional and traditional products (Paustian, Reinecke, Theuvsen, 2016). In the European Union, the region-of-origin can be distinguished between two different GI labels, i.e. the Protected Designation of Origin (PDO) and the Protected Geographical Indication (PGI), which are regulated by the Regulation (EC) 510/2006 (Paustian, Reinecke, Theuvsen, 2016). Farmers and processors can commercialize domestic food through short chains without intermediaries, or in other cases, by engaging the minimum possible number of intermediaries (Fernández-Ferrín et al., 2018; Holcomb et al., 2016; Renting, Marsden, Banks, 2003). As the channels of the sale and promotion of and communication between actors, digital media provide direct contacts between producers and consumers (Rakic Rakic, 2017a, Rakic, Rakic, 2017b). An increasing number of manufacturers open pages on Facebook and orders in other social media, which allows them a quick sale and simple communications with consumers in real time. The local-food interest is also apparent in food-related books and programs (Bianchi, Mortimer, 2015; Nabham, 2002).

Consumer demand for local food has risen (Bianchi, Mortimer, 2015; FernándezFerrín et al., 2018; Penney, Prior, 2014). The previous literature has addressed the concepts of local, regional and traditional products as if they were independent concepts. In practice, however, many food products combine all of the three concepts (Fernández-Ferrín et al., 2018). Local food is usually defined as the food produced, retailed and consumed in a specific geographical area (Bianchi, Mortimer, 2015). The local product is that produced and consumed locally and the geographical proximity gives it a superior quality with regard to the taste, freshness, and sustainability. Local products are defined according to the geographical proximity of their production to consumption. There are two criteria usually used for the purpose of geographical delimitation. The first measures the distance between the location of production and the location of consumption. The second criterion is related to political-administrative boundaries, such as counties, states or provinces (Fernández-Ferrín et al., 2018). The regional product is that produced locally, which may or may not be consumed outside that environment, and which offers a superior quality derived from the specific 
conditions of its identifiable geographical origin (Fernández-Ferrín et al., 2018). The traditional product is that produced locally, which may or may not be consumed outside that environment, and which offers the quality level stemming from tradition and the geographical origin (Fernández-Ferrín et al., 2018). Traditional food products are defined by European consumers as those "frequently consumed or associated with specific celebrations and / or seasons, transmitted from one generation to another, made in a specific way according to gastronomic heritage, naturally processed, and distinguished and known because of its sensory properties and associated with a certain local area, region or country" (Vanhonacker et al., 2010, p. 454). For the purpose of this study, the term "domestic food products" is used to refer to local, regional and traditional food products in Serbia.

The literature has identified a number of the reasons for purchasing local foods, which can be broadly divided into food-focused motivations, societal and ecological motivations. Food-focused motivations are: the quality of food (the taste, nutritional values, its shelf-life, appearance, and maturity), food safety, the origin (as the key information) (Paustian, Reinecke, Theuvsen, 2016). Personal motivations for buying local include: it is more pleasurable (a better taste, connectedness with rural life); it is perceived as healthier (fresher, eaten during a season, containing fewer chemicals, taking less time to transport and store) and safer than non-local food because the traceability of such food is made possible (Bianchi, Mortimer, 2015). Local products are considered as fresher, more nutritious and tastier than other products. A higher quality is derived from the geographical proximity between the production of such food and its consumption, which shortens the transportation time, thus allowing the optimum maturation and the use of fewer preservatives (Fernández-Ferrín et al., 2018; Galli, Brunori, 2013; Groves, 2005).

Societal motivations for buying local include: providing support to local business, small-scale producers or family-owned enterprises, the economy and employment; generating local jobs (Bianchi, Mortimer, 2015; Fernández-Ferrín et al., 2018; Lang, Stanton, Qu, 2014; Martinez et al., 2010; Morris, Buller, 2003), safeguarding jobs, supporting the regional industry (Paustian, Reinecke, Theuvsen, 2016), the preservation of a local heritage and tradition (Paustian, Reinecke, Theuvsen, 2016; Seyfang, 2006; Fernández-Ferrín et al., 2018) and local food culture, regional culinary traditions and the traditional methods of cultivating, producing and preparing food (Dansero, Puttilli, 2013; Fernández-Ferrín et al., 2018), as well as the preservation of the local identity and culture (Galli, Brunori, 2013; Groves, 2005).

Ecological motivations are inclusive of purchasing local food because it is perceived to be more environmentally sustainable (fewer food miles) (Bianchi, Mortimer, 2015), climate-friendly, and offering animal welfare (Paustian, Reinecke, Theuvsen, 2016). The benefits of the proximity between the producers, on the one hand, and the consumers of domestic food, on the other, are associated with the values related to sustainability. Local consumption reduces the use of fuels and chemicals, as well as greenhouse gas emissions (Fernández-Ferrín et al., 2018; Karner, 2010; La Trobe, 2002). 


\section{Method}

The present study of CE has the focus on identifying:

- the factors influencing $\mathrm{CE}$

- the demographic and other variables influencing ethnocentric consumer behavior

- the typologies of consumers with the degrees of ethnocentrism (based on CETSCALE).

The objective of this study is to identify the key actors and the activities of the actors influencing the ethnocentric behavior of the consumers of foodstuffs in Serbia.

Before the research design for collecting primary data is formulated, the relevant secondary data is analyzed. The Serbian Government produces large amounts of secondary data. The documentation published in the form of reports and guidelines on the web-site of the Ministry of Agriculture, Forestry and Water Management (http:// www.minpolj.gov.rs/) is an important source.

Consumers choose and buy products, and (un)consciously decide on the survival and profit of companies. Therefore, consumers are selected as respondents. Focus group is an appropriate research method for consumer research. Qualitative research based on focus group provides insights and understanding of the objective setting. The key criterion for selecting the members of the focus group was the respondents' ethnocentric orientation. The focus group included 12 students in the master studies in the field of business, who are responsible for buying food for their homes and who are ethnocentrically oriented as consumers.

The items of modified CETSCALE (Figure 1) was presented to the respondents and used as the framework for the face-to-face interview. The two basic questions were: 1. who (which actors) and 2. what (which activities) should the actors take in order to encourage $\mathrm{CE}$.

Figure 1. Modificated 17-Item CETSCALE as guide for interview

\footnotetext{
Item

1. Serbian people should always buy Serbian-made food products instead of imports.

2. Only those food products that are unavailable in Serbia should be imported.

3. Buy Serbian-made food products. Keep Serbia working.

4. Serbian food products first, last, and foremost.

5. Purchasing foreign-made food products is un-Serbian.

6. It is not right to purchase foreign food products, because it puts Serbians out of jobs.

7. A real Serbian should always buy Serbian-made food products.

8. We should purchase food products manufactured in Serbia instead of letting other countries get rich off us.

9. It is always best to purchase Serbian food products.

10. There should be very little trading or purchasing of food products from other countries unless out of necessity.
} 
11. Serbians should not buy foreign food products, because this hurts Serbian business and causes
unemployment.
12. Curbs should be put on all imports.
13. It may cost me more in the long-run, but I prefer to support Serbian food products.
14. Foreigners should not be allowed to put their products on our markets.
15. Foreign food products should be taxed by higher taxes heavily to reduce their entry in Serbia.
16. We should buy from foreign countries only those food products that we cannot obtain within our
own country.
17. Serbian consumers who purchase food products made in other countries are responsible for putting
their fellow Serbians out of work.

Source: Based on Shimp and Sharma, 1987.

\section{Results of research and discussion}

First, the analysis was conducted on the external secondary data displayed on the website of the Ministry of Agriculture, Forestry and Water Management (http:/www. minpolj.gov.rs/). By searching and analyzing the content displayed on the website, the following documents were extracted:

- the mark of a higher quality: "Serbian Quality"

- the list of the agricultural and food products with the mark of the geographical origin that were certified in 2017 or are still undergoing the certification process

- the certification authorities authorized by the Ministry to conduct control of the quality and special features of the agricultural and food products with the marks of the geographical origin.

The "Serbian Quality" mark is a national mark of a higher quality by means of which agricultural and food products are labelled with the aim of informing domestic and foreign consumers about the special features of such products. The mark guarantees the quality of the products characterized by specific features, first of all those manufactured from the raw materials from the territory of the Republic of Serbia and possessing a proved higher quality in comparison with the products of the same category in the market. This voluntary standard of quality is regulated by the Regulation on the Marking of Agricultural and Food Products with the "Serbian Quality" National Mark of a Higher Quality. The Ministry of Agriculture is responsible for conducting the procedure of marking agricultural and food products with the "Serbian Quality" mark (Ministry of Agriculture, Forestry and Water Management, 2018).

A conclusion may be drawn that the companies which can do so should position themselves on the basis of the "Serbian Quality" mark of a higher quality and the geographical origin.

The results of the research study and the extensive discussions between the moderator and the respondents are the answers to the two questions. The first question was: Who can influence CE? The respondents answered: consumers, governments, schools, producers, retailers and the media. All actors in the supply chain can contribute to CE 
encouraging. CE has an influence on domestic foodstuffs consumption, the profit of companies and Serbia's GDP.

The second question was: What (which activities) should the actors take in order to encourage $\mathrm{CE}$ ? Based on the discussions of the focus-group participants, the conclusions about the key activities of the actors that are in the function of stimulating consumer ethnocentrism are highlighted (Figure 2).

In the decision-making process, consumers can choose domestic products over foreign products. The respondents agree that consumers' responsibility is important. Also, the respondents agree that: "many products are ours, but we don't know it because there is no product labelling". Consumers can actively engage and communicate information about the importance of purchasing domestic products. Creating, raising and sharing content on the Internet is important for informing the public about the importance of consumer ethnocentrism. Companies and governments can influence consumer engagement on the Internet.

Governments (state and local governments, Government's appropriate ministries), chambers of commerce and associations - they all have the greatest opportunity to act on the behavior of all actors. Governments can influence the macro-environment, provide incentives to domestic producers, and create campaigns that encourage the purchase of domestic products.

Teachers in schools and at faculties can present and encourage CE. The subjects in which this is possible to do (for example in the fields of economics, agriculture, etc.), one teaching unit can be dedicated to $\mathrm{CE}$. Teachers can encourage discussions about $\mathrm{CE}$ in their lectures, exercises, creative workshops, at conferences and seminars.

The media can create and promote content in the function of $\mathrm{CE}$ encouraging. In the digital environment, digital media users become content producers - digital prosumers (users as producers and consumers of content). Online users can quickly share information with a large auditorium. Influentials have an opportunity to disseminate a CE promoting content.

Figure 2. The activities of the actors in the function of stimulating consumer ethnocentrism

- The purchase of domestic products

\section{Consumers}

- Engaging on social networks and in social media, and promoting $\mathrm{CE}$

- WOM communications in traditional and digital contexts

\section{Governments (State and Local)}

-An impact on the macro-environment-the political, economic, socio-cultural, technological, legal and ecological environments for the production of quality domestic products

- Incentives to domestic producers

- Campaigns encouraging CE; creating an image of a good quality of domestic products can influence consumer awareness of the importance of purchasing domestic products

- Encouraging retailers to better position domestic products 


\section{Schools}

- Consuming domestic products in school kitchens

- The presentation of CE in lectures, workshops, at seminars and conferences

- Presenting CE in books and journals

The Media

- Content in the function of CE encouraging

- Marketing Mix -4Ps

\section{Producers}

- Product: the production and supply of domestic products, a focus on the quality and the product quality control; the labeling of domestic products

- Price - determining the prices at which buyers can buy products

- Place - marketing channels: the constant availability of products in marketing channels

- Promotion - integrated marketing communications: promoting domestic products, encouraging consumers to buy and promote the purchase of domestic products, engaging reference individuals and influential persons

- Marketing mix - 7Ps

\section{Retailers}

- Product -the assortment of products: domestic products

- Price - determining the prices at which buyers can buy products

- Place - the availability of domestic products

- Promotion - integrated marketing communications: promoting domestic products

- People - friendly and helpful sellers presenting domestic products at the point of sale

- Process - the process of providing services that encourage the purchase of domestic products

\section{Source: Authors}

Profit often depends on marketing activities. Producers can contribute to the promotion of ethnocentrism through the marketing mix (the four instruments - 4Ps). First, products can be produced from domestic inputs, with a focus on the quality and quality control and a clear label, confirming that they are domestic products. Domestic products can be differentiated with respect to their respective features, quality, durability and labeling. Second, the price is a critical element of the marketing mix. Producers must determine the prices at which buyers can buy products. Third, decisions on selecting proper marketing channels are among the most critical decisions producers are faced with. Marketing channels serve markets; however, they also make markets. Effective channel management allows the availability of a product in channels. Fourth, the role of promotion and integrated marketing communications is to inform, persuade and remind consumers to buy domestic products. Producers can engage reference individuals and influential persons to promote domestic products in both traditional and digital media.

Retailers can use 7 marketing tools (7Ps) to influence consumers. They are in a better position than the producers because they are in direct contact with consumers. First, they can have domestic products in their assortment of products. A growing trend for retailers concerns a private-label brand (also called the distributor, store or reseller brand). Second, the decision on prices must be in accordance with customers' purchasing 
power. Third, the place as an instrument of the marketing mix can refer to decisions on the location of the store and the positioning of domestic products. There is a saying that the three keys to a retailer's success are: the location, the location, and the location. Fourth, retailers can use integrated marketing communications in promoting domestic products. Fifth, friendly and helpful sellers can present domestic products at the point of sale. Sixth, retailers must decide on the services mix to be offered to customers. Seventh, additionally, the three keys to a success of domestic products in stores are: positioning, positioning and positioning.

\section{Conclusion}

The findings demonstrate interesting implications for actors regarding marketing activities, as well as for researchers regarding further research in to both regional and local CE.

The actors - governments, schools, producers, retailers, the media and consumers can encourage $\mathrm{CE}$ by the production, distribution, consumption and presentation of the benefits of domestic food products.

The Government can influence the other actors to behave ethnocentrically in the purchase and consumption of products, create conditions in the macro-environment for all the other actors, and wage campaigns in order to encourage CE.

School curricula, the agendas of scientific conferences and seminars, food-related books, programs in the media - they all have an opportunity to present CE.

Manufacturers and retailers are in contact with consumers and can exert influence on their choices and behaviours in the context of product purchase and consumption. To create effective marketing programs and labels, it is necessary that the key factors affecting consumers' preferences for domestic products should be known. A potential basis for the positioning and differentiation of domestic food products, producers and retailers is: the quality (raspberries, etc.), the geographical proximity between production and consumption, the specific geographical origin of products (raspberries of Arilje, the homemade ayvar of Leskovac, the lamb of Sjenica, the cow cheese of Sjenica, the honey of Djerdap, etc.); the uniqueness of the culture, traditions and methods of production (the peppers and pepper products of Leskovac, such as the homemade ayvar of Leskovac, the barbeque meat and meat specialities of Leskovac, the paprika-flavored sausage of Srem, the pork rinds of Valjevo).

In marketing, that "the consumer is the king" is generally known. Consumer behavior depends on a number of factors. It is necessary that consumers be informed about, persuaded and reminded of the importance of ethnocentric behavior. All the other actors can influence the consumer awareness of the importance of purchasing domestic products.

\section{Conflict of interests}

The authors declare no conflict of interest. 


\section{References}

1. Alfnes, F. (2004). Stated preferences for imported and hormone-treated beef. Application of a mixed logit model. European Review of Agricultural Economics, 31(1), 19-37. doi: https://doi.org/10.1093/erae/31.1.19

2. Arsil, P., Li, E., Bruwer, J., \& Lyons, G. (2013). Exploring consumer motivations towards buying local fresh food products: a means-end chain approach. British Food Journal, 116(10), 1533-1549. doi: https://doi.org/10.1108/BFJ-04-2013-0083

3. Autio, M., Collins, R., Wahlen, S., \& Anttila, M. (2013). Consuming nostalgia? The appreciation of authenticity in local food production. International Journal of Consumer Studies, 37(5), 564-568. doi: https://doi.org/10.1111/ijcs.12029

4. Balabanis, G., Mueller, R., \& Melewar, T. C. (2002). The relationship between consumer ethnocentrism and human values. Journal of Global Marketing, 15(3/4), 7-37. doi: https://doi.org/10.1300/J042v15n03_02

5. Bianchi, C., \& Mortimer, G. (2015). Drivers of local food consumption: a comparative study. British Food Journal, 117(9), 2282-2299. doi: https://doi. org/10.1108/BFJ-03-2015-0111

6. Booth, K. (1979). Strategy and Ethnocentrism. Croom-Helm, London.

7. Carpio, C., \& Isengildina-Massa, O. (2009). Consumer willingness to pay for locally grown products: the case of South Carolina. Agribusiness, 25(2), 412-426. doi: https://doi.org/10.1002/agr.20210

8. Chung, Ch., Boyer, T., \& Han, S. (2009). Valuing quality attributes and country of origin in the Korean Market. Journal of Agricultural Economics, 60, 682-698. doi: https://doi.org/10.1111/j.1477-9552.2009.00218.x

9. Coderre, F., Boivin, C., \& Etaabaa, I. (2010). Measuring retailers' commitment toward regional foods: the CIBLE-chaire bombardier index. British Food Journal, 112(11), 1190-1204. doi: https://doi.org/10.1108/00070701011088188

10. Costanigro, M., Kroll, S., Thilmany, D., \& Bunning, M. (2014). Is it love for local/ organic or hate for conventional? Asymmetric effects of information and taste on labels preferences in an experimental auction. Food Quality and Preference, 31, 94-105. doi: https://doi.org/10.1016/j.foodqual.2013.08.008

11. Cvijanović, D., Ignjatijević, S., Milivojević, I., \& Mihailović, B. (2016). Potentials of Serbia in international frameworks - importance of agriculture and health tourism. Faculty of Hotel Management and Tourism, Vrnjacka Banja, Serbia. [in Serbian: Cvijanović, D., Ignjatijević, S., Milivojević, I., \& Mihailović, B. (2016). Potencijali Srbije u međunarodnim okvirima - značaj poljoprivrede i zdravstvenog turizma. Fakultet za hotelijerstvo i turizam u Vrnjačkoj banji, Republika Srbija].

12. Dansero, E., \& Puttilli, M. (2013). Multiple territorialities of alternative food networks: six cases from Piedmont, Italy. Local Environment: The International Journal of Justice and Sustainability, 19(6), 626-643. doi: https://doi.org/10.1080/ 13549839.2013 .836163 
13. Darby, K., Batte, M., Ernst, S., \& Roe, B. (2008). Decomposing local: a conjoint analysis of locally produced foods. American Journal of Agricultural Economics, 90(2), 476-486. doi: https://doi.org/10.1111/j.1467-8276.2007.01111.x

14. Đurić, D., Ristić, J., Đurić, D., \& Vujanić, I. (2017). Export of agricultural and food products in the function of economic growth of Republic of Serbia. Economics of Agriculture, 64(3), 887-900.

15. Fernández-Ferrín, P., \& Bande-Vil, B. (2013). Regional ethnocentrism: Antecedents, consequences, and moderating effects. Food Quality and Preference, 30, 299-308. doi: https://doi.org/10.1016/j.foodqual.2013.06.011

16. Fernández-Ferrín, P., Bande, B., \& Galán-Ladero, M. M. (2017). Parental influence on levels of regional ethnocentrism of youth: an exploratory analysis. Spanish Journal of Marketing-ESIC, 21, 52-62. doi: https://doi.org/10.1016/j. sjme.2016.11.001

17. Fernández-Ferrín, P., Calvo-Turrientes, A., Bande, B., Artaraz-Miñón, M., \& GalánLadero, M. (2018). The valuation and purchase of food products that combine local, regional and traditional features: The influence of consumer ethnocentrism. Food Quality and Preference, 64, 138-147. doi: https://doi.org/10.1016/j. foodqual.2017.09.015

18. Galli, F., \& Brunori, G. (Eds.). (2013). Short food supply chains as drivers of sustainable development (Evidence Document). Retrieved from http:// www. foodlinkscommunity.net/fileadmin/documents_organicresearch/foodlinks/ CoPs/ evidence-document-sfsc-cop.pdf

19. Gašević, D., Tomašević, D., \& Vranješ, M. (2017). Key Factors Determining the Ethnocentric Tendencies of Consumers in Serbia. Management: Journal of Sustainable Business and Management Solutions In Emerging Economies, 22(3), 63-73. doi:10.7595/management.fon.2017.0028

20. Groves, A. (2005). The local and regional food opportunity (Research Report). Institute of Grocery Distribution (IGD), Watford.

21. Holcomb, R. B., Bendfeldt, E., Lelekacs, J., Velandia, M., Woods, T. A., Goodwin, H. L., \& Rainey, R. L. (2016). A local foods system glossary: A rose by any other name. In: Paper presented at the Annual Meeting of the Southern Agricultural Economics Association, San Antonio, Texas

22. Huddleston, P., Good, L. K., \& Stoel, L. (2001). Consumer ethnocentrism, product necessity and Polish consumers' perceptions of quality. International Journal of Retail and Distribution Management, 29(5), 236-246. doi: https://doi. org/10.1108/09590550110390896

23. Ilbery, B., Watts, D., Simpson, S., Gilg, A., \& Little, J. (2006). Mapping local foods: evidence from two English regions. British Food Journal, 108(3), 213-215. doi: https://doi.org/10.1108/00070700610651034 
24. Javalgi, R., Khare, V., Gross, A., \& Schere, R. (2005). An application of the consumer ethnocentrism model to French consumer. International Business Review, 14, 325 344. doi: https://doi.org/10.1016/j.ibusrev.2004.12.006

25. Karner, S. (Ed.). (2010). Local food systems in Europe: Case studies from five countries and what they imply for policy and practice (FAAN Project Booklet). Retrieved from http:/www.faanweb.eu/sites/ faanweb.eu/files/FAAN_Booklet PRINT.pdf.

26. Kovljenić, M., \& Savić, M. (2017). Factors influencing meat and fish consumption in Serbian households - evidence from silc database. Economics of Agriculture, 64(3), 945-956.

27. Kragulj, D., Parežanin, M., \& Miladinović, S. (2017). Consumer ethnocentrism in transitional economies: Evidence from Serbia. Sociološki pregled, 51(1), 59-79.

28. Lang, M., Stanton, J., \& Qu, Y. (2014). Consumers' evolving definition and expectations for local foods. British Food Journal, 116(11), 1808-1820. doi: https:// doi.org/10.1108/BFJ-03-2014-0117

29. La Trobe, H. (2002). Local food, future directions (FOE Research Report). Retrieved from http://www.foe.co.uk/sites/default/files/downloads/local_food_directions.pdf

30. Marinković, V., Stanišić N., \& Kostić M. (2011). Consumer Ethnocentrism of Serbian Citizens. Sociologija, LIII(1), 43-58.

31. Martinez, S., Hand, M., Da Pra, M., Pollack, S., Ralston, K., Smith, T., \& Newman, C. (2010). Local food systems: Concepts, impacts and issues (Economic Research Report No. 67). Retrieved from https:/www.ers.usda.gov/webdocs/publications/ err97/7054_err97_1_.pdf.

32. Ministry of Agriculture, Forestry and Water Management. (2018). Serbian Quality. Retrieved from http://www.minpolj.gov.rs/srpski-kvalitet/

33. Morris, C., \& Buller, H. (2003). The local food sector: a preliminary assessment of its form and impact in Gloucestershire. British Food Journal, 105(8), 559-566. doi: https://doi.org/10.1108/00070700310497318

34. Nabham, G. (2002). Coming Home To Eat: The Pleasures And Politics Of Local Foods. Norton, New York, NY.

35. Orth, U.R., \& Firbasová, Z. (2003). The Role of Consumer Ethnocentrism in Food Product Evaluation. Agribusiness, 19(2), 137-153. doi: https://doi.org/10.1002/ agr. 10051

36. Ouellet, J. F. (2007). Consumer racism and its effects on domestic cross-ethnic product purchase: An empirical test in the United States, Canada, and France. Journal of Marketing, 71(1), 113-128.

37. Paustian, M., Reinecke, F-E., \& Theuvsen, L. (2016). Consumer preferences for regional meat products. British Food Journal, 118(11), 2761-2780. doi: https://doi. org/10.1108/BFJ-01-2016-0002 
38. Penney, U., \& Prior, C. (2014). Exploring the urban consumer's perception of local food. International Journal of Retail \& Distribution Management, 42(7), 580-594. https://doi.org/10.1108/IJRDM-09-2012-0077

39. Poon, P., Evangelista, F., \& Albaum, G. (2010). Attitudes of migrants towards foreignmade products: An exploratory study of migrants in Australia. Journal of Consumer Marketing, 27(1)35-42. doi: https://doi. org/10.1108/07363761011012930

40. Rakic, B., \& Rakic, M. (2015a). Holistic management of sustainability marketing in the process of sustainable development. Environmental Engineering and Management Journal, 14(4), 887-900.

41. Rakic, M., \& Rakic, B. (2015b). Sustainable Lifestyle Marketing of Individuals: the Base of Sustainability. Amfiteatru Economic, 17(40), 891-908.

42. Rakic, B., \& Rakic, M. (2017a). From Marketing Myopia to Contemporary Marketing: Transformations in Marketing in the Context of Digitalization and Sustainability (Integration of Traditional, Digital, Co-Creative and SustainabilityOriented Mindsets Inside Actors in Contemporary Marketing). Digital Book, available at eBook retailers: Amazon.com - Kindle Store, etc.

43. Rakic, B., \& Rakic, M. (2017b). Sustainability-Oriented Mindset: Revolutionary Role of Sustainability Marketing as the Driver of Transformations for Sustainability, Digital Book, available at eBook retailers: Amazon.com - Kindle Store, etc.

44. Rakic, B., \& Rakic, M. (2018). Collaborative partnership paradigm in the sustainability-oriented supply chain as the way to sustainability. Applied ecology and environmental research, 16(3), 2639-2650. doi: http://dx.doi.org/10.15666/ aeer/1603_26392650

45. Renting, H., Marsden, T., \& Banks, J. (2003). Understanding alternative food networks: exploring the role of short food supply chains in rural development. Environment and Planning A: Economy and Space, 35, 393-411. doi: https://doi. org/10.1068/a3510

46. Schnettler, B., Miranda, H., Lobos, G., lveda, J.S., \& Denegri, M. (2011). A study of the relationship between degree of ethnocentrism and typologies of food purchase in supermarkets in central-southern Chile. Appetite, 56, 704-712. doi: https://doi. org/10.1016/j.appet.2011.02.007

47. Shankarmahesh, M. N. (2006). Consumer ethnocentrism: an integrative review of its antecedents and consequences. International Marketing Review, 23(2), 146-172. doi: https://doi.org/10.1108/02651330610660065

48. Shimp, T.A., \& Sharma, S. (1987). Consumer ethnocentrism: construction and validation of the CETSCALE. Journal of Marketing Research, 24, 280-289. doi: $10.2307 / 3151638$ 
49. Siemieniako, D., Kubacki, K., Glińska, E., \& Krot, K. (2011). National and regional ethnocentrism: a case study of beer consumers in Poland. British Food Journal, 113(3)404-418. doi: https://doi.org/10.1108/00070701111116464

50. Seyfang, G. (2006). Ecological citizenship and sustainable consumption: examining local organic networks. Journal of Rural Studies, 22(4), 383-395. doi: https:/doi. org/10.1016/j.jrurstud.2006.01.003

51. Sumner, W.G. (1906). Folkways: The Sociological Importance of Usages, Manners, Customs, Mores, and Morals, Ginn \& Co., New York, NY.

52. Šmaižien,I., \& Vaitkien, R. (2014). Consumer ethnocentrism and behavior in a market of dietary supplements. Procedia - Social and Behavioral Sciences, 156, pp.463-467. doi: https://doi.org/10.1016/j.sbspro.2014.11.222

53. Vanhonacker, F. et al. (2010). How European consumers define the concept of traditional food: Evidence from survey in six countries. Agribusiness, 26(4), 453476. doi: https://doi.org/10.1002/agr.20241

54. Verbeke, W., \& Ward, R. W. (2006). Consumer interest in information cues denoting quality, traceability and origin. An application of ordered probit models to beef labels. Food Quality and Preference, 17, 453-467. doi: https://doi.org/10.1016/j. foodqual.2005.05.010

55. Verlegh, P. W. J., Steenkamp, J.B.E.M., \& Meulenberg, M. (2005). Country-oforigin effects in consumer processing of advertising claims. International Journal of Research in Marketing, 22,127-139. https://doi.org/10.1016/j.ijresmar.2004.05.003 